\title{
PRESENT AND PAST GLACIATION THRESHOLD IN THE CASGADE RANGE, WASHINGTON, U.S.A.: TOPOGRAPHIC AND CLIMATIC CONTROLS, AND PALEOGLIMATIC IMPLICATIONS
}

\author{
By Stephen C. Porter \\ (Department of Geological Sciences and Quaternary Research Center, University of \\ Washington, Seattle, Washington 98195, U.S.A.)
}

Aвstract. Isoglacihypses depicting the configuration of the glaciation threshold (="glaciation limit") in Washington broadly parallel the crest of the Cascade Range and curve around the west and south flanks of the Olympic Mountains. In both uplands the glaciation threshold rises inland (eastward) with a mean gradient of $10-12 \mathrm{~m} / \mathrm{km}$. However, the gradient in the Cascades is more variable $(7-25 \mathrm{~m} / \mathrm{km}$ ) due to five east-trending troughs in the glaciation threshold surface that coincide with topographic depressions along the range crest and that apparently result from greater eastward penetration of moist maritime air.

Mean accumulation-season precipitation correlates strongly $\left(r^{2}=0.86\right)$ with altitude of the glaciation threshold in the North Cascade Range, but the correlation of glaciation threshold with altitude of the July freezing isotherm, determined from the calculated July lapse rate within the mountains, is much weaker $\left(r^{2}=0.40\right)$. Multiple regression analysis relating independent climatic variables that affect the height of the glaciation threshold indicates that $90.4 \%$ of variance is explained by accumulation-season precipitation and estimated mean annual temperature at the glaciation threshold.

The glaciation threshold during the greatest ice advance of the last (Fraser) glaciation in the southern North Cascade Range (c. 18 000-22 000 years B.P.) was $900 \pm 100 \mathrm{~m}$ below that of the present. Depression of the glaciation threshold by this amount most likely resulted from a change in accumulation-season precipitation of no more than $30 \%$ from present values and a decrease in mean ablation-season temperature of $5.5 \pm 1.5$ deg.

Résumé. Seuils des glaciations presentes et passées dans la Cascade Range, Washington, U.S.A.: controles topographiques et climatiques et implications paléoclimatiques. Les isoglaciohypses qui décrivent la configuration du seuil de glaciation (limite des zones englacées) dans le Washington sont grossièrement parallèles à la crête de la Cascade Range et s'incurvent autour des flancs ouest et sud des Olympic Mountains. Dans les deux massifs, le seuil de glaciation s'élève vers l'intérieur (vers l'Est) avec un gradient moyen de 10 à $12 \mathrm{~m} / \mathrm{km}$. Cependant, le gradient dans les Cascades est plus variable $(7$ à $25 \mathrm{~m} / \mathrm{km})$ en raison de la présence de cinq extensions allongées vers l'Est dans la surface englacée qui coïncident avec des dépressions topographiques le long de la crête de la chaîne et qui provoquent apparemment une plus grande pénétration vers l'Est de l'air maritime humide.

Les précipitations moyennes de la saison d'accumulation sont étroitement correlées $\left(r^{2}=0,86\right)$ avec l'altitude du seuil de glaciation dans la North Cascade Range, mais la corrélation du seuil de glaciation avec l'altitude de l'isotherme $0^{\circ}$ en juillet, déterminée par le calcul des vitesses d'érosion en juillet dans les montagnes, est beaucoup plus faible $\left(r^{2}=0,40\right)$. L'analyse par regressions multiples rapportée aux variables climatiques indépendantes qui influent sur la hauteur du seuil de glaciation indique que $90,4 \%$ de la variance s'explique par les précipitations de la saison d'accumulation et par la température moyenne annuelle estimée au seuil de glaciation.

Le seuil de glaciation pendant l'avance maximum de la dernière glaciation (Fraser) dans le Sud de la North Cascade Range (de 18 ooo à 22000 avant nos jours) était de $900 \pm 100 \mathrm{~m}$ en-dessous du niveau actuel. Un tel abaissement du seuil de glaciation doit probablement résulter d'un changement de pas plus de $30 \%$ des valeurs de la précipitation actuelle en saison d'accumulation et d'une diminution de la température moyenne en saison d'ablation de $5,5 \pm 1,5 \mathrm{deg}$.

Zusammenfassung. Derzeitige und fruhere Vergletscherungsgrenze in der Cascade Range, Washington, U.S.A.: topographische und klimatische Einflüsse sowie paläoklimatische Folgerungen. Kurven der Vereisungshöhe (Isoglacihypsen), welche die Lage der Vergletscherungsgrenze beschreiben, laufen in Washington weitgehend parallel zum Kamm der Cascade Range und umrunden die West- und Südflanke der Olympic Mountains. In beiden Gebirgsgegenden steigt die Vergletscherungsgrenze landein (ostwärts) mit einem mittleren Gradienten von $10-12 \mathrm{~m} / \mathrm{km}$ an. Doch schwankt der Gradient in den Cascades stärker $(7-25 \mathrm{~m} / \mathrm{km})$ infolge von 5 ostwärts gerichteten Trögen in der Fläche der Vergletscherungsgrenze, die mit topographischen Einsenkungen längs des Kammes zusammenfallen und offensichtlich durch das stärkere Vordringen von maritimer Feuchtluft nach Osten verursacht sind.

Der mittlere Niederschlag in der Akkumulationsperiode ist stark korreliert $\left(r^{2}=0,86\right)$ mit der Höhe der Vergletscherungsgrenze in der nördlichen Cascade Range; die Korrelation der Vergletscherungsgrenze mit der Höhe der Null-Grad-Isotherme im Juli, bestimmt aus der berechneten Gleitrate innerhalb des Gebirges, ist dagegen weit schwächer $\left(r^{2}=0,40\right)$. Aus der Vielfach-Regressionsanalyse zwischen den klimatschen Parametern, die Einfluss auf die Höhe der Vergletscherungsgrenze haben, lassen sich $90,4 \%$ der Schwankungen aus dem Niederschlag während der Akkumulationsperiode und der geschätzten mittleren Jahrestemperatur an der Vergletscherungsgrenze erklären. 
Die Vergletscherungsgrenze lag während des Maximums der letzten (Fraser) Vereisung in der südlichen North Cascade Range (etwa 18 ooo bis 20 ooo Jahre vor der Gegenwart) $900 \pm 1$ oo m tiefer als heute. De Absenkung der Vergletscherungsgrenze um diesen Betrag wurde aller Wahrscheinlichkeit nach durch eine Änderung des Niederschlags in der Akkumulationsperiode von nicht mehr als $30 \%$ gegenüber den derzeitigen Werten und eine Abnahme der mittleren Temperatur in der Ablationsperiode von 5,5 $\pm 1,5$ deg bewirkt.

\section{INTRODUGTION}

Approximately three-quarters of the glacier-covered area of the United States south of Alaska lies in the state of Washington (Meier, 196r). A recent inventory of glaciers in the North Cascade Range indicates that more than half of this ice resides in 756 bodies of perennial ice larger than $0 . \mathrm{I} \mathrm{km}^{2}$ and having a total area of $267 \mathrm{~km}^{2}$ (Post and others, I97 I). Although the general distribution and altitudinal range of these glaciers have been determined, to date no analysis has been made of possible regional controls on glacier distribution.

Post and others (I97 I) concluded that it was virtually impossible to construct a consistent regional map of glacier altitudes in the Cascades because of non-uniformity of glacier orientation, of configuration of cirque walls, of occurrence of snow avalanches, and of efficiency of accumulation basins to trap wind-drifted snow. Consequently, in this study regional aspects of glacier distribution were investigated by determining the glaciation threshold* for the glacier-covered mountains of the state and then comparing this parameter with topographic and meteorologic data. Maps of the glaciation threshold have been constructed for adjacent parts of the Cordillera in British Columbia (Østrem, 1966), but the present study is the first to extend such information south of the international boundary into the Cascades of Washington.

The glaciation threshold is not strictly equivalent to the regional snow line (Charlesworth, I 957, p. I I) or to the equilibrium line on glaciers (Paterson, I969, p. 3I), but it has been used as a reasonable approximation for them because it is thought to lie nearly parallel to the regional snow line but at a higher altitude. Where suitable topographic base maps are available, the glaciation threshold offers a rapid means of analyzing the regional altitudinal distribution of glaciers and of evaluating possible controlling factors.

\section{DETERMinATION OF THE GLAGIATION THRESHOLD}

The glaciation threshold was computed as the arithmetic mean of the altitude of the lowest glacier-clad summit and the highest glacier-free mountain within any $7 \frac{1}{2}$ min topographic quadrangle map. The contour interval on most U.S. Geological Survey quadrangle sheets for the Cascade Range is either 40 or $80 \mathrm{ft}$ [ 12 or $24 \mathrm{~m}$ ] and the area of a quadrangle at this latitude is about $128 \mathrm{~km}^{2}$. Heights of peaks lacking surveyed summit altitudes were taken as the highest contour shown. Resulting values, determined for all of the glaciercovered areas of the state, were plotted on a base map with each data point located at the mid-point of a quadrangle. Isoglacihypses, which are lines of equal altitude of the glaciation threshold and depict its regional configuration, were then constructed by contouring ten data points for the Olympic Mountains and 78 data points for the Cascade Range (Fig. I).

* Enquist (1916, p. 10-1 I) proposed the term "Vergletscherungsgrenze" for the critical height at which glaciers form. Ahlmann (1948) and Østrem (1964, I966) subsequently used the English equivalent "glaciation limit" which became rather widely adopted. Later, Østrem (I972) suggested a substitute term, "glaciation level", to avoid possible confusion resulting from the use of "glaciation limit" by some geologists in describing the outer limit of a drift sheet. The substitute term is misleading, however, for the surface derived by the "summit method" (Partsch, 1882) commonly is neither flat nor horizontal, as the word "level" implies (Onions, 1955), nor is it an appropriate translation of Vergletscherungsgrenze. An alternative term, glaciation threshold, is employed here, for "threshold" is a suitable translation of the German word "grenze" (Betteridge, 1958), the expression adequately connotes the concept Enquist was describing, and it avoids both the possible ambiguity of "glaciation limit" and the inaccuracy of "glaciation level". 
Accuracy of computed values for the glaciation threshold depends largely on contour interval of the base maps and potential positioning error of data points (the distance between the center and corner of a quadrangle, in this case a maximum of about $8 \mathrm{~km}$ ). The latter factor is significant where the local gradient of the glaciation threshold is steep. Maximum potential error in the derived glaciation threshold values is considered to be about $\pm 50 \mathrm{~m}$, but in most instances probable error is closer to half this value.

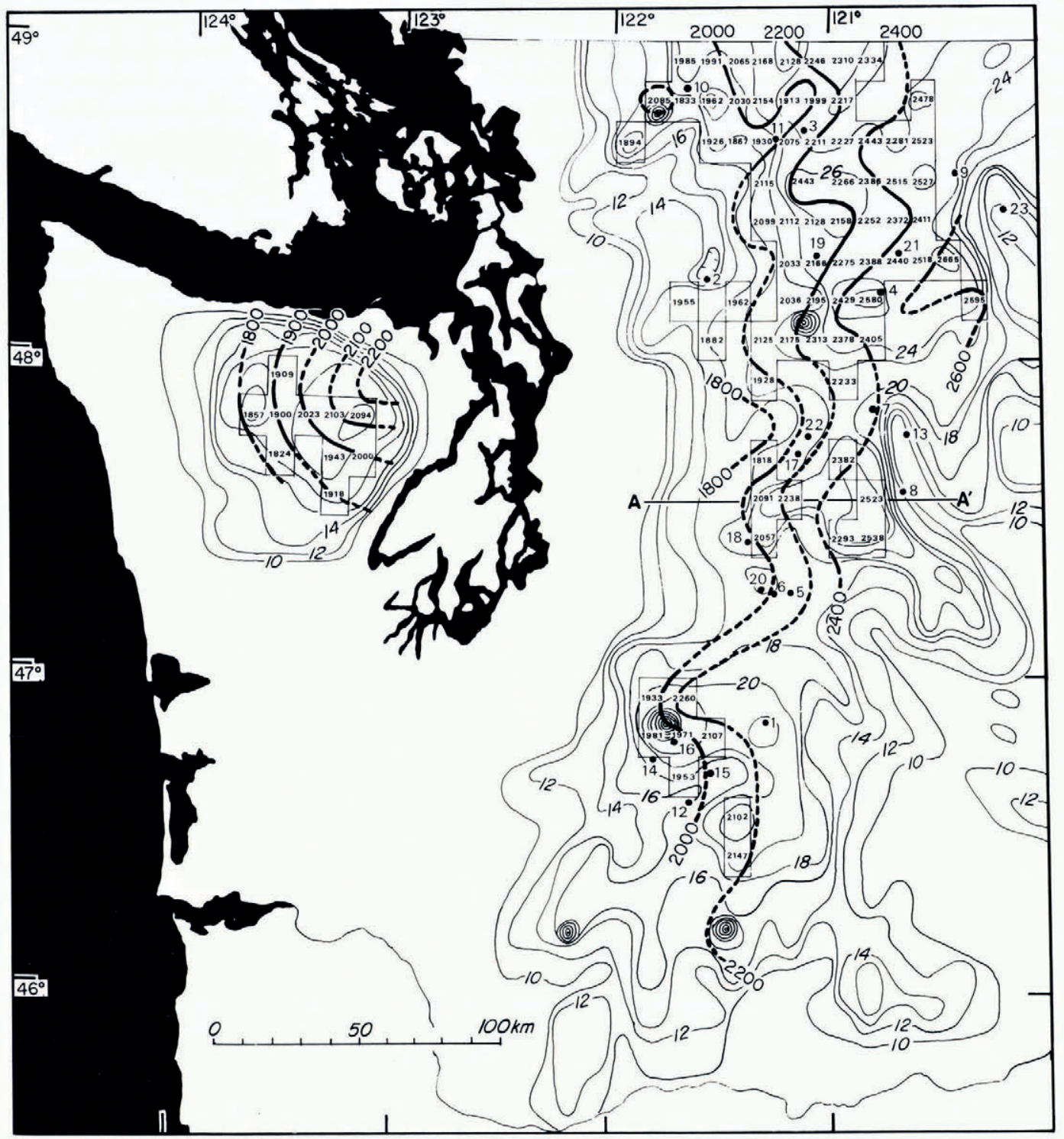

Fig. I. Map of western Washington showing gross summit topography (contours in hundreds of meters) and isoglacihypses (heavy lines) depicting the configuration of the glaciation threshold (meters). Mean altitude of the glaciation threshold within each glacierized quadrangle is given in meters. Numbered points (1-23) are locations of meteorological stations within the Cascade Range (see Table I). 


\section{Configuration AND GRADIENT OF THE GLACIATION THRESHOLD}

Isoglacihypses for the Cascade Range broadly parallel the Pacific Coast and the crest of the mountain range. However, superimposed on this regional trend are local irregularities dominated by five east-trending troughs spaced at intervals of approximately $60 \mathrm{~km}$. Because of lower summit altitudes in the southern Cascades, glaciers are few in number; most cluster about the slopes of the large stratovolcanoes. Consequently, in this part of the state the glaciation threshold is definable for only a narrow belt along the crest of the range. The glaciation threshold rises inland, increasing in altitude from I $800 \mathrm{~m}$ near the west margin of the range to more than $2600 \mathrm{~m}$ at the eastern limit of glaciers. Its gradient is variable, ranging from as little as $7 \mathrm{~m} / \mathrm{km}$ near the axes of the east-trending troughs to as much as $25 \mathrm{~m} / \mathrm{km}$, but averaging about $12 \mathrm{~m} / \mathrm{km}$. Isoglacihypses in the Olympic Mountains curve around the west and south sides of the upland, increasing in altitude rather uniformly towards the north and east with an average gradient of about $10 \mathrm{~m} / \mathrm{km}$.

Gradients of the glaciation threshold in Washington are similar to those determined for the Southern Alps of New Zealand which, like the Olympic Mountains and Cascades, are a mid-latitude mountain range lying in a belt of westerly air flow in a strongly maritime climatic regime (Porter, I975[b]). In both areas, the average gradient is far steeper than that determined for glacier-clad regions at higher latitudes (Fig. 2). At latitudes of $60^{\circ}$ or more, measured

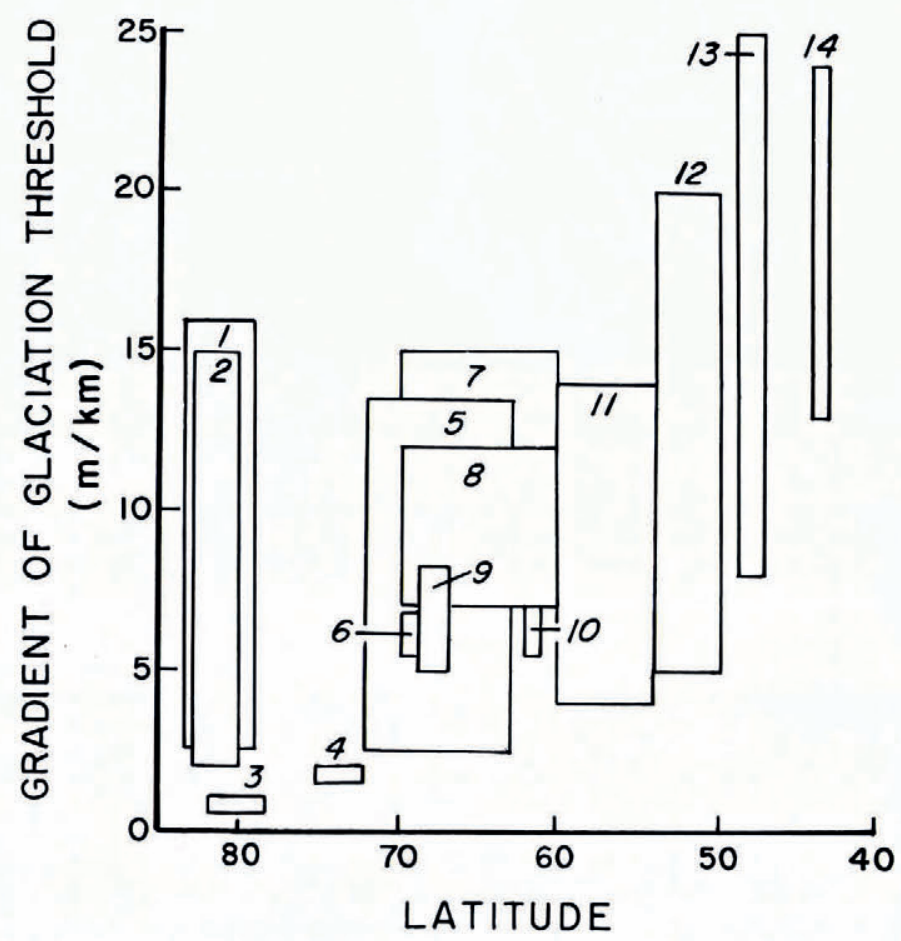

Fig. 2. Latitudinal variation of glaciation-threshold gradients for maritime coastal mountain ranges. I. Vorthern Greenland (Weidick, 1975); 2. High Canadian Arctic (Miller and others, 1975); 3. Severnaya Zemlya (ELA) (Grosval'd and Kotylakov, I969); 4. Novaya Zemlya (ELA) (Grosval'd and Kotylakov, I969); 5. Baffin Island (Andrews and Miller, I972); 6. Northern Norway (Andersen, 1968); 7. South-east Greenland (Weidick, 1975); 8. West Greenland (Weidick, I968, 1975); 9. Northern Sweden (Østrem, 1964); Io. Southern Sweden (Østrem, 1964); I I. Northern British Columbia and south-eastern Alaska (Østrem, I972); 12. Southern British Columbia (Østrem, I966); 13. Cascade Range and Olympic Mountains (this study); 14. Southern Alps, New Zealand (Porter, 1975[b]). 
glaciation-threshold gradients in maritime coastal mountains are less than $15 \mathrm{~m} / \mathrm{km}$ and generally less than $10 \mathrm{~m} / \mathrm{km}$ (Østrem, I964; Andersen, I968; Miller and others, I975; Weidick, 1975). Between lat. $70^{\circ}$ and $80^{\circ}$ N. in the Soviet Arctic, regional gradients of the equilibrium-line altitude of glaciers, which should approximately parallel the glaciation threshold, are less than $2 \mathrm{~m} / \mathrm{km}$ (Grosval'd and Kotylakov, I969). The gross latitudinal variation of glaciation-threshold gradients shown in Figure 2 may largely reflect a precipitation control, for where the gradients are steepest, maximum precipitation is very high $(>4000 \mathrm{~mm})$ and precipitation gradients are steep. By contrast, glaciation-threshold gradients commonly are much gentler in the polar regions where maximum precipitation seldom reaches $2000 \mathrm{~mm}$ annually. The north-west coast of Ellesmere Island (lat. $82^{\circ}$ to $83^{\circ}$ N.) is an exception. Possibly the unusually steep gradient there (up to $15 \mathrm{~m} / \mathrm{km}$ ) is related to local temperature or precipitation anomalies that may be due to persistent open water off the coast (Miller and others, 1975; personal communication from J. T. Andrews, I975).

\section{FAGTORS CONTROLLING THE GLAGIATION THRESHOLD}

In previous studies of the glaciation threshold, attempts have been made to evaluate factors controlling its height and configuration. The most relevant parameters are topography, accumulation-season precipitation and ablation-season temperature, for these clearly are important in determining glacier location and mass balance (Østrem, 1972; Miller and others, 1975; Porter, 1975[b]).

Both Østrem (1972) and Porter (1975[b]) have concluded that topography plays a significant role in establishing the configuration of isoglacihypses in coastal Alaska and British Columbia, and in New Zealand, respectively. Specifically, moist maritime air masses are able to penetrate farther inland where topographic saddles occur along a range crest, resulting in local depression of the glaciation threshold as indicated by leeward lobation of isoglacihypses through such reaches.

In few areas are meteorological data adequate to evaluate possible correlation of climatic parameters with the position of the glaciation threshold. Weidick (1968) suggested that the glaciation threshold in West Greenland was controlled by both summer temperature and annual precipitation, and concluded that summer temperature at sea-level was the factor providing the highest positive correlation $(r=0.76)$. Andrews and Miller (1972) estimated the mean level of the July freezing isotherm over Baffin Island using surface-temperature data from 27 stations and an assumed lapse rate of $0.75 \mathrm{deg} / \mathrm{I} 00 \mathrm{~m}$. They concluded tentatively that this factor may correlate rather strongly with the height of the glaciation threshold $(r=0.64-0.84)$. However, Miller and others (1975) found no significant relationship between July freezing level and the height of the glaciation threshold in the high Canadian Arctic, although a high correlation has been found between equilibrium-line altitude and the height of the mean July freezing level (Bradley, 1975). Precipitation may be a major control in that area, but the available evidence was inadequate to make a proper evaluation. In most other studies, possible climatic controls have been suggested intuitively because climatic data are inadequate for an analysis. For example, in the Southern Alps of New Zealand only a single weather station lies within the area covered by isoglacihypses, and it lies about $3000 \mathrm{~m}$ below the tops of nearby glacier-clad peaks (Porter, r 975[b]).

The Cascade Range of Washington provides an especially good setting for this kind of evaluation, for a rather large number of meteorological stations is scattered throughout the range and most have records extending over 30 years or more. The 23 stations within the mountains used for this analysis cover a variety of local climatic environments on both sides of the drainage divide and range in altitude from I6o to I $844 \mathrm{~m}$ (Fig. I; Table I). All but 
Table I. Climatic data and glaciation threshold for Cascade Range, Washington

\begin{tabular}{|c|c|c|c|c|c|c|c|}
\hline Station & $\begin{array}{l}\text { Station } \\
\text { altitude } \\
\mathrm{m}\end{array}$ & $\begin{array}{c}\mathrm{km} \\
\text { from } \\
\text { divide } \\
\text { and } \\
\text { direction }\end{array}$ & $\begin{array}{l}\text { Glaciation } \\
\text { threshold } \\
\mathrm{m}\end{array}$ & $\begin{array}{c}\text { Mean } \\
\text { annual } \\
\text { precipita- } \\
\text { tion } \\
\text { mm* }\end{array}$ & $\begin{array}{c}\text { Mean } \\
\text { accumulation- } \\
\text { season } \\
\text { (Oct.-Apr.) } \\
\text { precipita- } \\
\text { tion } \\
\text { mm* }\end{array}$ & $\begin{array}{c}\text { Mean } \\
\text { annual } \\
\mathcal{T} \\
{ }^{\circ} \mathbf{C}^{*}\end{array}$ & $\begin{array}{c}\text { Mean } \\
\text { July } \\
T \\
{ }^{\circ} \mathbf{C}^{*}\end{array}$ \\
\hline I. Bumping Lake & I 049 & ${ }_{15} \mathrm{E}$. & $2325 \pm 50$ & 1215 & I 06 I & $4 \cdot 7$ & 14.6 \\
\hline 2. Darrington R.S. & 168 & $46 \mathrm{~W}$. & $1950 \pm 25$ & 2045 & I 704 & $9 \cdot 7$ & 17.4 \\
\hline 3. Diablo Dam & 272 & $35 \mathrm{~W}$. & $2100 \pm 25$ & 1818 & I 548 & 9.1 & 18.3 \\
\hline 4. Holden & 1 047 & I I $\mathrm{E}$. & $2575 \pm 5^{\circ}$ & 899 & 759 & 5.9 & 16.8 \\
\hline 5. Lake Kachess & 692 & I I E. & $2100 \pm 25$ & I 395 & I 207 & 6.7 & 17.4 \\
\hline 6. Lake Keechelus & 754 & 4 E. & $2025 \pm 25$ & 1731 & I 488 & $6 . \mathrm{I}$ & 15.8 \\
\hline 7. Lake Wenatchee & 690 & $21 \mathrm{E}$. & $2400 \pm 25$ & I 033 & 914 & 一 & - \\
\hline 8. Leavenworth & 354 & $33 \mathrm{E}$. & $2600 \pm 50$ & 607 & 523 & 9.0 & 20.9 \\
\hline 9. Mazama & 598 & $22 \mathrm{E}$. & $2600 \pm 50$ & 480 & 372 & - & - \\
\hline Io. Mount Baker Lodge & I 324 & $70 \mathrm{~W}$. & I $850 \pm 50$ & 2790 & 2148 & $4 \cdot 5$ & 12.2 \\
\hline I I. Newhalem & 160 & $35 \mathrm{~W}$. & $2000 \pm 25$ & I 987 & I 656 & 10.1 & I8.6 \\
\hline 12. Packwood & 323 & $21 \mathrm{~W}$. & I $975 \pm 25$ & 1 $35^{6}$ & I 154 & - & $\overline{0}$ \\
\hline 13. Plain & 549 & $34 \mathrm{E}$. & $2575 \pm 50$ & 632 & 544 & 7.2 & 18.3 \\
\hline I4. Rainier (Longmire) & 842 & $34 \mathrm{~W}$. & I $900 \pm 50$ & 2094 & 1719 & $7 \cdot 3$ & 16.2 \\
\hline I5. Rainier (Ohanepecosh) & 587 & 1o W. & $2000 \pm 25$ & I 837 & I $5^{84}$ & 一 & - \\
\hline I6. Rainier (Paradise) & I 692 & 2 I W. & I $975 \pm 25$ & 2635 & 2137 & $3 \cdot 4$ & I 1.6 \\
\hline I 7. Scenic & 678 & $7 \mathrm{~W}$. & $2100 \pm 25$ & 2110 & I 764 & 一 & - \\
\hline 18. Snoqualmie Pass & 917 & 0 & I $950 \pm 25$ & 2733 & 2275 & $5 \cdot 4$ & $14 \cdot 3$ \\
\hline 19. South Cascade Glacier & I 844 & $2 \mathrm{~W}$. & $2150 \pm 25$ & $239^{\text {d }}$ & - & I.9 & 9.8 \\
\hline 20. Stampede Pass & I 206 & & I $950 \pm 25$ & 2342 & I 929 & $\begin{array}{l}4.2 \\
8 \cdot 2\end{array}$ & $\begin{array}{l}13.4 \\
10.2\end{array}$ \\
\hline 21. Stehekin & 351 & $28 \mathrm{E}$. & $245^{\circ} \pm 25$ & 859 & $\begin{array}{r}75^{8} \\
58\end{array}$ & 8.2 & 19.2 \\
\hline $\begin{array}{l}\text { 22. Stevens Pass } \\
\text { 23. Winthrop }\end{array}$ & $\begin{array}{r}1245 \\
535\end{array}$ & $\begin{array}{l}\mathrm{O} \\
35 \mathrm{E} .\end{array}$ & $\begin{array}{l}2100 \pm 25 \\
2700 \pm 50\end{array}$ & $\begin{array}{r}1919 \\
370\end{array}$ & $\begin{array}{r}1582 \\
271\end{array}$ & $\begin{array}{l}4 \cdot 3 \\
7 \cdot 1\end{array}$ & 20.1 \\
\hline & $\begin{array}{c}\text { Mean } \\
\text { ablation- }\end{array}$ & \multicolumn{3}{|c|}{$\begin{array}{c}\text { Estimated altitude }(m) \text { of } 0^{\circ} \mathrm{C} \\
\text { isotherm }\end{array}$} & \multicolumn{3}{|c|}{$\begin{array}{l}\text { Estimated mean } T\left({ }^{\circ} \mathrm{C}\right) \text { at } \\
\quad \text { glaciation threshold }\end{array}$} \\
\hline Station & $\begin{array}{c}\text { season } \\
\text { (May-Sept.) } \\
{ }_{\boldsymbol{T}}{ }^{\circ} \mathrm{C}^{*}\end{array}$ & Annual $^{\mathrm{a}}$ & Fulyb & $\begin{array}{l}\text { Ablation } \\
\text { seasonc }^{\mathrm{c}}\end{array}$ & Annual ${ }^{\mathrm{a}}$ & Fuly $\mathrm{b}^{\mathrm{b}}$ & $\begin{array}{c}\text { Ablation } \\
\text { season }^{\mathrm{c}}\end{array}$ \\
\hline I. Bumping Lake & 1 1.6 & 2049 & 3228 & 2920 & -1.3 & 6.1 & $3 \cdot 7$ \\
\hline 2. Darrington R.S. & I 5.4 & 2232 & 2765 & 2652 & 1.3 & $5 \cdot 5$ & $4 \cdot 4$ \\
\hline 3. Diablo Dam & I 5.8 & 2208 & 3003 & 2820 & 0.5 & 6.1 & $4 \cdot 3$ \\
\hline 4. Holden & I 3.6 & 2302 & 3554 & 3241 & -1.3 & 6.6 & 4.1 \\
\hline 5. Lake Kachess & $14 \cdot 3$ & 2 I 8 & 3289 & 2998 & o. I & 8.0 & 5.6 \\
\hline 6. Lake Keechelus & 12.9 & $205^{2}$ & 3 II 2 & 2835 & 0.1 & $7 \cdot 3$ & 5.0 \\
\hline 7. Lake Wenatchee & $\overline{17.7}$ & - & - & - & - & - & $\overline{28}$ \\
\hline $\begin{array}{l}\text { 8. Leavenworth } \\
\text { 9. Mazama }\end{array}$ & 17.7 & $2 \underline{269}$ & $3 \underline{473}$ & 3209 & -1.5 & $\underline{5 \cdot 9}$ & 3.0 \\
\hline Io. Mount Baker Lodge & 10.1 & $228 I$ & 3145 & 2953 & 2.0 & 8.7 & 6.8 \\
\hline I I. Newhalem & I6.5 & 2309 & 2936 & 2821 & 1.5 & 6.3 & 5.1 \\
\hline 12. Packwood & - & - & - & - & - & - & - \\
\hline 13. Plain & I 4.9 & 2081 & 3280 & $295^{2}$ & -2.3 & $4 \cdot 7$ & 2.3 \\
\hline I4. Rainier (Longmire) & I 3.5 & 2395 & 3260 & 3019 & 2.3 & $9 \cdot \mathrm{I}$ & 6.9 \\
\hline I5. Rainier (Ohanepecosh) & - & $\overline{1}=$ & 一 & - & $\bar{a}$ & $\overline{0}$ & $\overline{7.2}$ \\
\hline $\begin{array}{l}\text { I6. Rainier (Paradise) } \\
\text { I } 7 . \text { Scenic }\end{array}$ & $9 \cdot 0$ & 2415 & $3 \underline{423}$ & 3 I 44 & 2.1 & $\underline{9 \cdot 7}$ & 7.2 \\
\hline 18. Snoqualmie Pass & 11.7 & 2066 & 3051 & 2804 & 0.5 & $7 \cdot 4$ & $5 \cdot 3$ \\
\hline 19. South Cascade Glacier & - & 2248 & 3307 & - & 0.5 & $7 \cdot 7$ & \\
\hline 20. Stampede Pass & 10.7 & 2100 & 3206 & 2932 & 0.7 & 8.4 & 6.1 \\
\hline 21. Stehekin & I6.0 & 2096 & 3217 & 2932 & -1.7 & 5.1 & 3.0 \\
\hline 22. Stevens Pass & 10.7 & 2160 & 3290 & 2971 & 0.3 & 8.0 & $5 \cdot 4$ \\
\hline 23. Winthrop & I6.6 & 2046 & 3535 & 3212 & -3.1 & 5.6 & 3.2 \\
\hline
\end{tabular}

* Period of record 1931-6o. a Assumed lapse rate $=0.47 \mathrm{deg} / 100 \mathrm{~m}$ (Fig. 4).

b Assumed lapse rate $=0.67 \mathrm{deg} / 100 \mathrm{~m}$ (Fig. 4).

c Assumed lapse rate $=0.62 \mathrm{deg} / 100 \mathrm{~m}$ (Fig. 4).

d Value adjusted to account for wind-drifted snow (personal communication from W. A. Tangborn, 1975). 
five lie within the North Cascades, where the position of the isoglacihypses is most closely controlled. Because only a single meteorological station occurs within the glacier-covered part of the Olympic Mountains, a similar analysis for that area was not feasible.

\section{Topographic control}

The control of topography on the configuration of the glaciation threshold was analyzed by constructing a contour map showing the smoothed summit surface of the mountainous areas of the state. The map was derived by dividing the western half of Washington into rectangles equivalent to $7 \frac{1}{2} \mathrm{~min}$ topographic quadrangles and calculating the mean maximum summit altitude for each rectangle. This was done by determining the mean altitude of the three highest peaks within each quadrangle and plotting the resulting value at the center of each rectangle in a grid array. Values higher than $\mathrm{I}$ ooo $\mathrm{m}$ were then contoured to depict the gross topographic configuration of the Cascade Range and the Olympic Mountains (Fig. I). By eliminating topographic detail below the generalized summit surface, one can better visualize the possible topographic control exerted by the mountains on eastwardmoving Pacific air masses, as well as the relationship of the isoglacihypses to the summit topography of these two uplands.

Isoglacihypses for the Cascades lie mainly on the western slope of the range, as defined by the summit contours. The gross north-south alignment of the isoglacihypses parallels the primary axis of the range. Each of the pronounced east-trending troughs coincides with a prominent topographic saddle across the crest of the range that lies at the eastern extremity of a prominent east- or north-east-trending topographic low in the summit surface. The lows coincide approximately with major stream valleys draining the west slope of the range. From north to south, these are the valleys of the Skagit, Suiattle, Skykomish, SnoqualmieCedar and Cowlitz Rivers. The topographic depressions in the summit surface, together with the underlying deeply eroded valleys cut in the western flank of the Cascades, apparently permit moist maritime air to penetrate farther east than at other places along the crest, thereby affecting the distribution of precipitation over the higher parts of the range and locally depressing the glaciation threshold through these sectors.

In contrast to the Cascades, the Olympic Mountains are marked by a gently eastwardand northward-rising summit surface on the west and south sides of the nearly circular upland, and by abrupt and steep eastern and northern margins (Fig. I). The isoglacihypses are confined to the higher north-eastern part of the upland, around which they form a series of concentric arcs. Their curved pattern, together with the pattern of isoglacihypses on central Vancouver Island constructed by Østrem (Ig66) which bend sharply east at their southern limit, suggest that a pronounced east-trending trough also occurs over southern Vancouver Island and the Strait of Juan de Fuca, coinciding with a major structural and topographic saddle in the coastal mountain system.

\section{Climatic control}

Precipitation commonly is regarded as a major factor controlling the altitude of the glaciation threshold, but in most previous studies data have been inadequate to evaluate its effect quantitatively. Comparison of glaciation-threshold maps with isohyetal maps generally shows a reasonable correspondence, with lowest precipitation values coinciding with highest glaciation threshold along any given transect normal to isoglacihypses (Østrem, 1966, I972; Porter, 1975[b]). The density of meteorological stations within the Cascades permits direct comparison of precipitation values with the height of the glaciation threshold and quantitative evaluation of the degree of correlation between the two.

Mean accumulation-season (October-April) precipitation for 22 stations shown on Figure I was plotted against altitude of the glaciation threshold above that station, and a 
least-squares regression curve fitted to the data (Fig. 3). In this case, $86 \%$ of the variance is explained by the least-squares regression line $\left(r^{2}=0.86\right) . *$ A similar plot employing mean annual precipitation produced a slightly lower correlation $\left(r^{2}=0.79\right)$. In the high Cascades annual precipitation values largely reflect heavy winter and spring snowfall $(83 \%$ of total annual precipitation), so the similar degree of correlation is not surprising. The highest glaciation-threshold values $(2600-2700 \mathrm{~m})$ occur as much as $35 \mathrm{~km}$ east of the drainage divide at places where mean accumulation-season precipitation is less than $600 \mathrm{~mm}$. Along

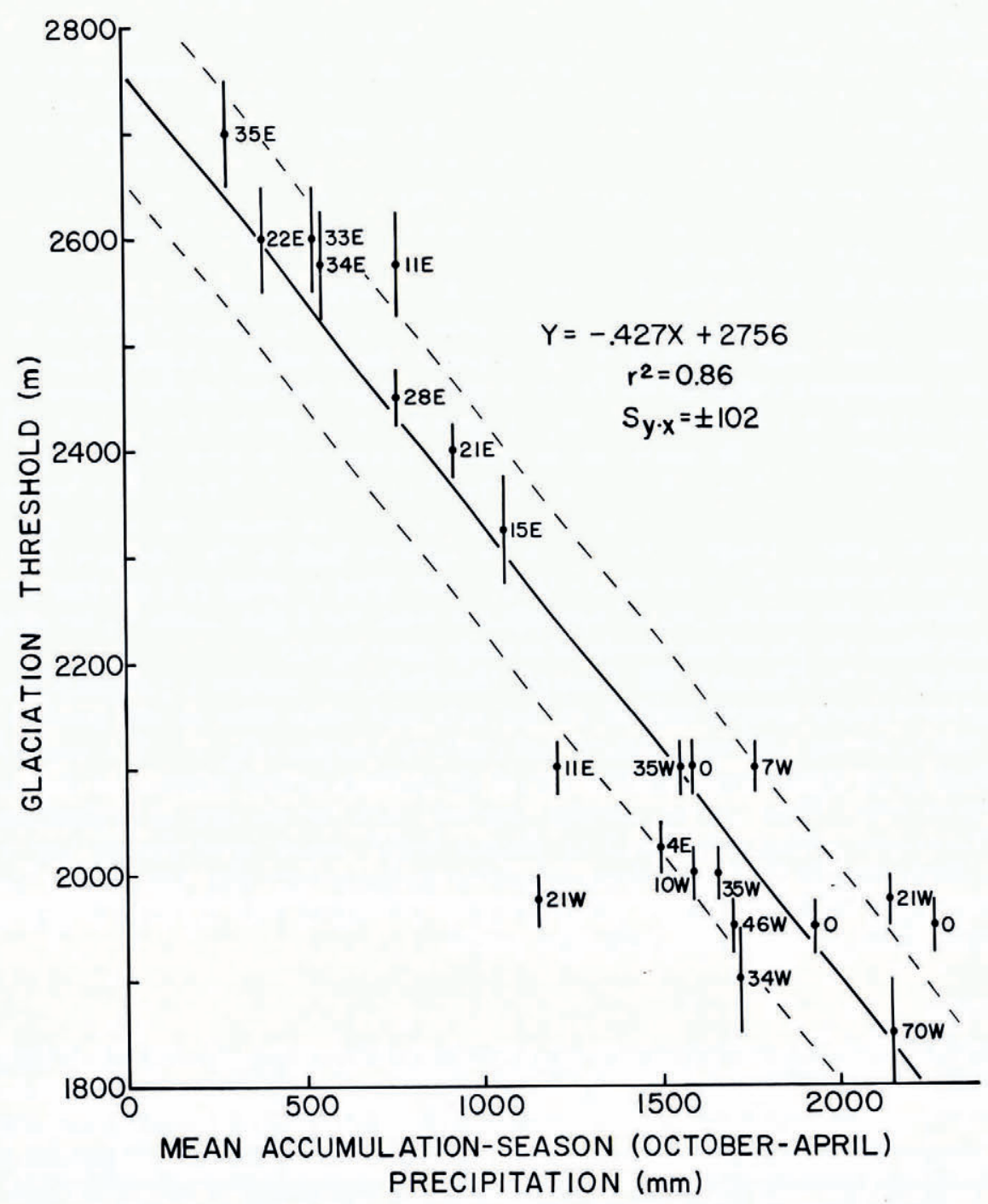

Fig. 3. Graphic relationship of mean accumulation-season prccipitation to altitude of the glaciation threshold. Standard error of estimates is shown by dashed lines.

* The anomalously high precipitation value for South Cascade Glacier, probably resulting largely from extensive wind-drifting of snow (personal communication from Wendell Tangborn, 1975), was omitted from the plot; if included, the coefficient of determination would fall to 0.79 . 
and west of the divide, precipitation increases to $1500 \mathrm{~mm}$ or more and the glaciation threshold is $500-850 \mathrm{~m}$ lower. Although the glaciation threshold generally lies more than $\mathrm{I}$ ooo $\mathrm{m}$ above meteorological stations in the range, annual precipitation is much more strongly related to longitude $(r=0.78)$ (distance east or west of the drainage divide) than it is to altitude $(r=0.47)$. Consequently, precipitation values recorded at ground stations probably do not differ significantly from the precipitation falling at the altitude of the glaciation threshold above any given station.

Correlation of temperature with height of the glaciation threshold is hampered by the difference in altitude between meteorological stations and the local glaciation threshold. Where mean temperature values derived from ground-based information at the glaciation threshold or from upper-air radiosonde data are not available, it has been common practice to estimate mean temperature at the glaciation threshold by applying a free-air lapse rate. Faced with a range of calculated local July lapse rates of 0.36 to $1.33 \mathrm{deg} / \mathrm{r} 00 \mathrm{~m}$ based on surface records, Andrews and Miller (1972) selected a value of $0.75 \mathrm{deg} / \mathrm{I} 00 \mathrm{~m}$ to derive an estimate of altitude of the July freezing isotherm over Baffin Island. In the present study, lapse rates for the Cascades have been calculated using long-term mean temperature values for ground stations within the range. The data, shown graphically in Figure 4, indicate a

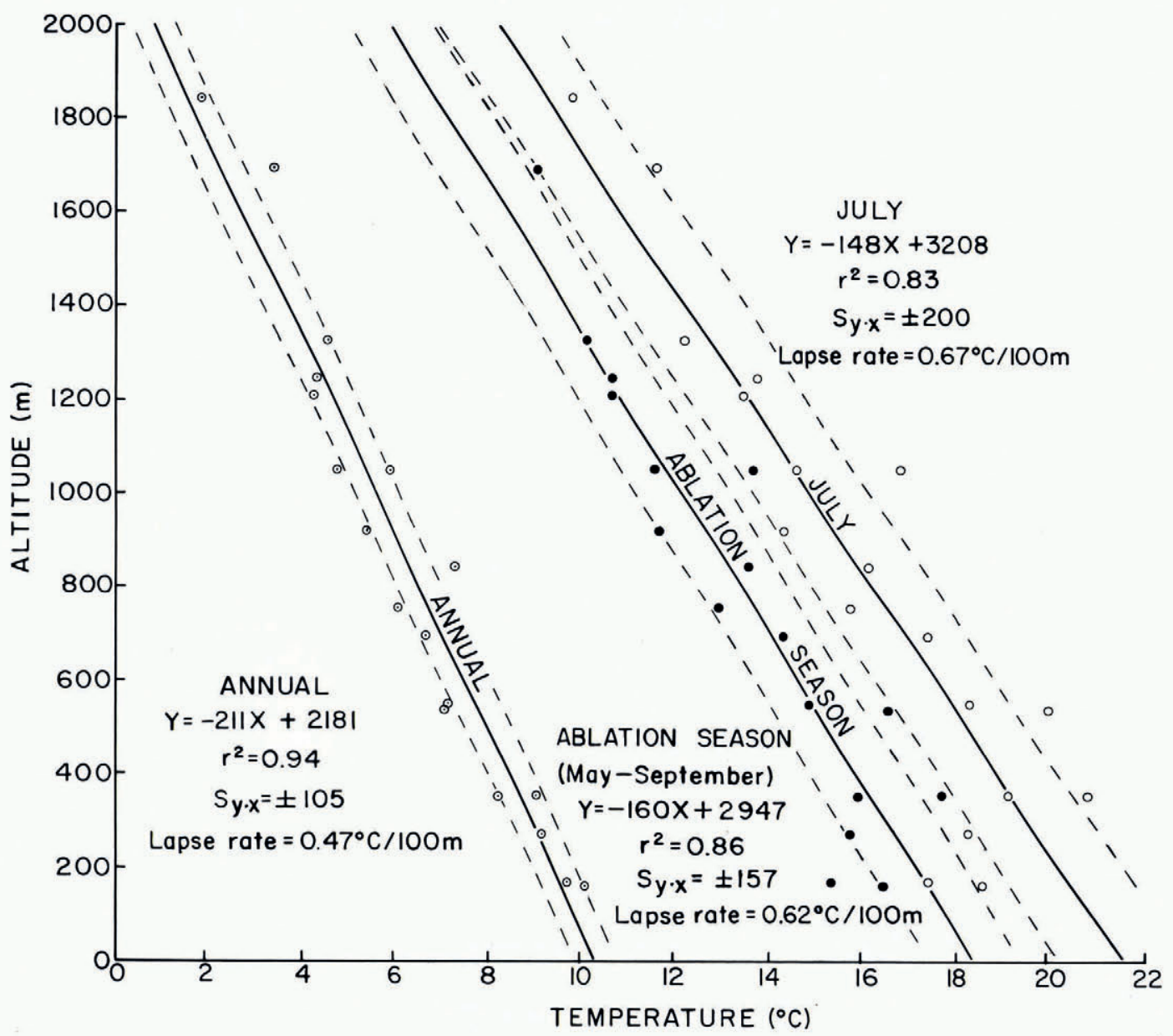

Fig. +. Mean annual, ablation-season and July lapse rates calculated from temperature data given in I able I. 
strong relationship $\left(r^{2}=0.94-0.83\right)$ between temperature and altitude. The calculated mean annual lapse rate is $0.47 \mathrm{deg} / \mathrm{I} 00 \mathrm{~m}$, whereas the mean ablation-season (May-September) lapse rate is $0.62 \mathrm{deg} / \mathrm{1} 00 \mathrm{~m}$ and the mean July lapse rate is $0.67 \mathrm{deg} / \mathrm{r} 00 \mathrm{~m}$. These values were used to derive both the estimated altitude of the freezing isotherm and the estimated mean temperature at the glaciation threshold, as listed in Table I.

To test the possible relationship between height of the glaciation threshold and the altitude of the freezing isotherm, separate plots were made relating glaciation threshold to estimated altitude of the annual, ablation-season and July $0^{\circ} \mathrm{C}$ isotherms. The strongest relationship ( $\left.r^{2}=0.40\right)$ was found in the case of the July freezing isotherm (Fig. 5). Use of the summer value leads to a slightly weaker relationship $\left(r^{2}=0.36\right)$; an almost negligible $\left(r^{2}=0.10\right)$ correlation was found with respect to the annual freezing isotherm. The results are somewhat comparable to those obtained by Andrews and Miller (1972) for Baffin Island.

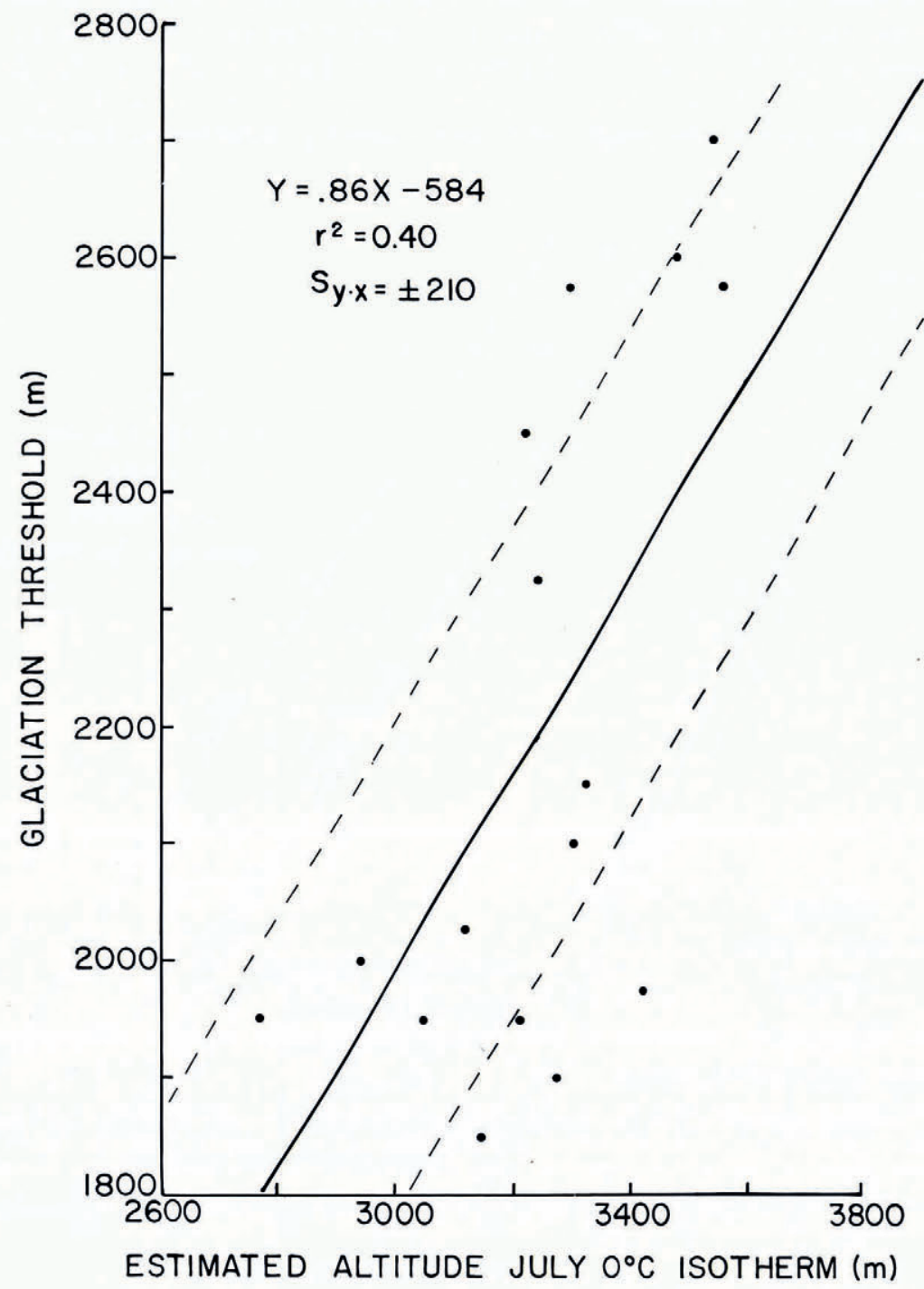

Fig. 5. Graphic relationship of the altitude of the mean July o $C$ isotherm to the altitude of the glaciation threshold. 
Because glacier mass balance is a function of both accumulation and ablation, the altitude of the glaciation threshold in the Cascades should reflect the combined effects of precipitation and temperature. Opinion varies as to whether annual, ablation-season or July temperature should constitute the dominant temperature control, and whether accumulation-season or annual precipitation is the more important. Consequently, a multiple stepwise correlation program was run with glaciation threshold given as a function of these five independent climatic parameters. The results indicate that $90.4 \%$ of the variance is explained by accumulation-season precipitation and estimated mean annual temperature at the glaciation threshold. The remaining variables (annual precipitation, mean ablation-season temperature and mean July temperature at the glaciation threshold) explain only an additional $4.1 \%$ of the variance. The remarkably high correlation $\left(r^{2}=0.8 \mathrm{I}\right)$ between estimated mean annual temperature and accumulation-season precipitation (Fig. 6) clearly demonstrates the compensating change of temperature related to the strong precipitation gradient across this maritime coastal mountain range. Near the drainage divide, where the glaciation threshold is about $2100 \mathrm{~m}$, mean accumulation-season precipitation is commonly close to $\mathrm{I} 500 \mathrm{~mm}$ and the estimated mean annual temperature at the glaciation threshold is close to freezing

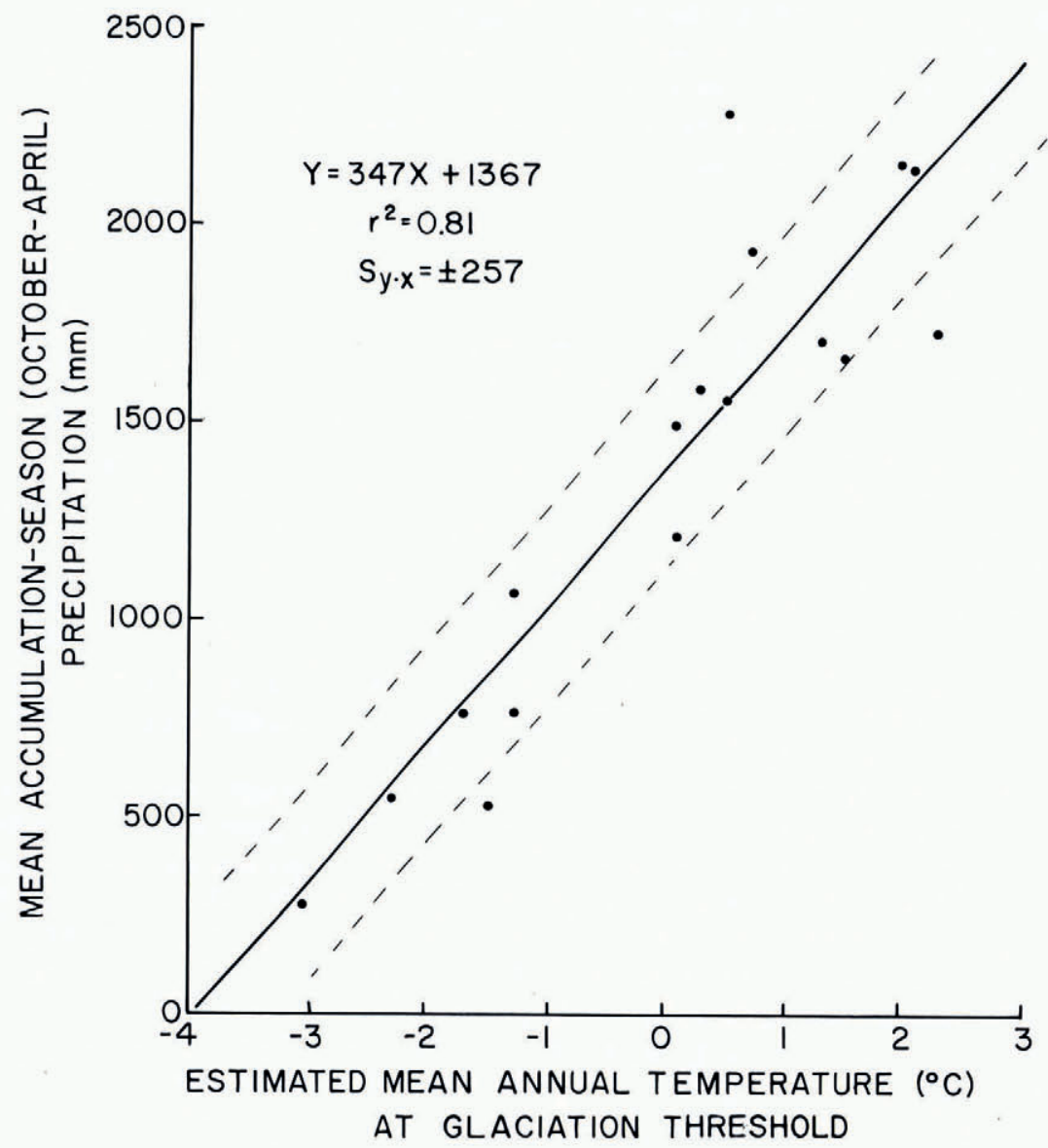

Fig. 6. Graphic relationship of mean accumulation-season precipitation to estimated mean annual temperature at the glaciation threshold. 
$\left(\mathrm{O} \pm \mathrm{I}^{\circ} \mathrm{C}\right)$. Precipitation increases west of the crest, reaching a maximum of more than $2100 \mathrm{~mm}$, and estimated mean annual temperature shows a corresponding increase to a maximum of about $2^{\circ} \mathrm{C}$. East of the divide, precipitation diminishes progressively and the glaciation threshold rises. At a distance of $35 \mathrm{~km}$ from the crest accumulation-season precipitation has fallen to only $300 \mathrm{~mm}$, and the glaciation threshold lies at $2600-2700 \mathrm{~m}$. At the same time, estimated mean annual temperature at the glaciation threshold has dropped to about $-3^{\circ} \mathrm{C}$.

The broader implications of these results are obvious. The frequently stated assumption that the glaciation threshold should coincide with the mean summer (or mean July) freezing isotherm can only be true under a limited range of conditions. In strongly maritime coastal mountains characterized by high precipitation regimes, ablation-season temperature at the glaciation threshold is likely to be well above freezing. An extreme example is provided by Blue Glacier in the Olympic Mountains, which receives close to $3500 \mathrm{~mm}$ of precipitation and has a mean summer temperature at the equilibrium line $(1700 \mathrm{~m})$ of about $7^{\circ} \mathrm{C}$ (Loewe, 197 I); the glaciation threshold at this location is only slightly higher (1 $850 \mathrm{~m}$ ). By contrast, in moisture-deficient polar or interior mountain systems, mean summer temperature at the glaciation threshold may lie below freezing. Such is the case, for example, at Penny Ice Cap on Baffin Island, where water-equivalent precipitation amounts to a scant $400 \mathrm{~mm}$ and summer temperature at the equilibrium line averages $-2^{\circ} \mathrm{C}$ (Loewe, 1971).

The high correlation of glaciation-threshold altitude with mean accumulation-season precipitation points up the significance of continentality in determining glacier distribution. As Østrem ( $\left[{ }^{\mathrm{c}} \mathrm{I}_{974]}\right)$ has emphasized, the glaciation threshold can constitute a convenient indicator of the degree of continentality for a given region.

\section{Glaciation threshold DURING the Fraser glaciation}

The magnitude of late Quaternary environmental changes in the Cascades can be evaluated by calculating the difference between the present and former glaciation threshold. This is analogous to determining the depression of equilibrium-line altitude (ELA) based on reconstructed glacier topography (Porter, I975[a]). The basic requirement, in addition to a knowledge of present glaciation threshold, is sufficiently detailed glacial-geologic mapping to provide information about which mountains formerly carried glaciers. In the Cascades, glacial-geologic mapping is not complete enough to permit reconstruction of isoglacihypses for the entire range at the last glacial maximum, nor for each of several intervals of glacier resurgence that followed (Porter, 1976). However, the mapping is adequate in some sectors to reconstruct the glaciation threshold along latitudinal transects perpendicular to the trend of the modern isoglacihypses, so that the difference between the present glaciation threshold and that of the last glacial maximum can be evaluated.

At the time of the greatest ice advance of the Fraser glaciation in the southern North Cascade Range, nearly all mountain summits lay well above the glaciation threshold. Only along the western margin of the range, where a few isolated summits are less than I ooo $\mathrm{m}$ high, and along the eastern margin, where some peaks reach altitudes between I 500 and $2000 \mathrm{~m}$, can the former glaciation threshold be fixed with any accuracy. The transect $\left(\mathrm{A}-\mathrm{A}^{\prime}\right)$ providing the best control data is located on Figure $\mathrm{I}$ and shown in cross-section in Figure 7. The control points fix the Fraser glaciation threshold between I 700 and I $900 \mathrm{~m}$ near the eastern margin of the range and between about $75^{\circ}$ and $1000 \mathrm{~m}$ at the western margin. Along the transect, the present and former glaciation thresholds are approximately parallel and separated by about $900 \pm 100 \mathrm{~m}$. This value is comparable to that derived by calculating the difference between present and former ELAs along this same transect (Porter, I975[a], p. 45). 


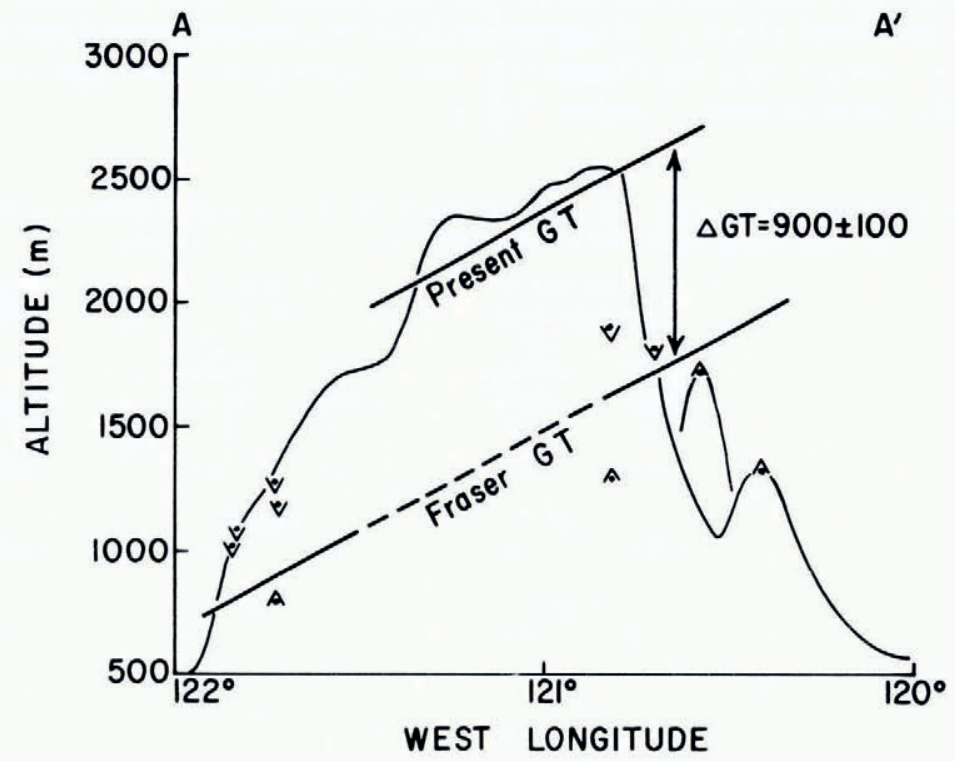

Fig. 7. Transed (.1 .1') across the southem. Sorth Cascade Range showing gross topography and difference between present glaciation threshold and that of the maximum Fraser ice adiance. Control points for delimiting Fraser glaciation threshold are shown near the west and east margins of the range.

\section{Paleoclimatic implications}

A unique solution for the temperature-precipitation regime at the last glacial maximum in the Cascades cannot be derived from the glaciation-threshold data because of the many possible combinations of these parameters that could result in a given lowering of the glaciation threshold. However, a reasonable range of values can be determined, based on the observed uniform lowering of the glaciation threshold across the range.

Three basic precipitation-related models can be envisioned, involving (a) no change in precipitation from the present, (b) increased precipitation, and (c) decreased precipitation. In order to derive specific values for temperature and precipitation changes in each case, a set of modern conditions is postulated from the data given in Table I and Figures $3-7$. At three points, spaced equally along a transect perpendicular to the drainage divide and to isoglacihypses, average glaciation threshold, accumulation-season precipitation and mean temperature values have been determined (Table II). These values constitute the standard from which departures are calculated, assuming a uniform depression of glaciation threshold by about $900 \mathrm{~m}$ at the maximum of the last glaciation.

If no change in precipitation occurred, uniform lowering of the glaciation threshold could result from temperature depression alone, assuming that the present lack of a discernible altitudinal precipitation gradient also was characteristic of the glacial maximum. In this

Table 11. Average glaciation threshold and climatic values across the North Cascade Range

Glaciation threshold $(\mathrm{m})$

Accumulation-season precipitation at glaciation threshold ( $\mathrm{mm}$ )

Temperature at glaciation threshold (C) Ablation season

Annual

\begin{tabular}{|c|c|c|}
\hline $\begin{array}{l}30 \mathrm{~km} \text { west } \\
\text { of divide }\end{array}$ & $\begin{array}{l}\text { At drainage } \\
\text { divide }\end{array}$ & $\begin{array}{l}30 \mathrm{~km} \text { east } \\
\text { of divide }\end{array}$ \\
\hline 1910 & $225^{\circ}$ & $259^{\circ}$ \\
\hline 1980 & 1200 & 400 \\
\hline $\begin{array}{l}6.5 \\
1.8\end{array}$ & $\begin{array}{r}4.4 \\
-0.5\end{array}$ & $\begin{array}{r}2.2 \\
-2.8\end{array}$ \\
\hline
\end{tabular}


case, a $900 \mathrm{~m}$ lowering would necessitate a uniform depression of ablation-season temperature at the glaciation threshold by $5.6 \pm 0.6 \mathrm{deg}$ across the entire transect, or a depression of mean annual temperature by $4.2 \pm 0.4 \mathrm{deg}$ (Table III), on the assumption that lapse rates of the last glaciation were the same as those of today (Fig. 4).

Table III. Change in temperature $(\Delta T)$ and precipitation $(\Delta P)$ required to produce a 900 m depression of glaciation threshold across the North Ciascade Range

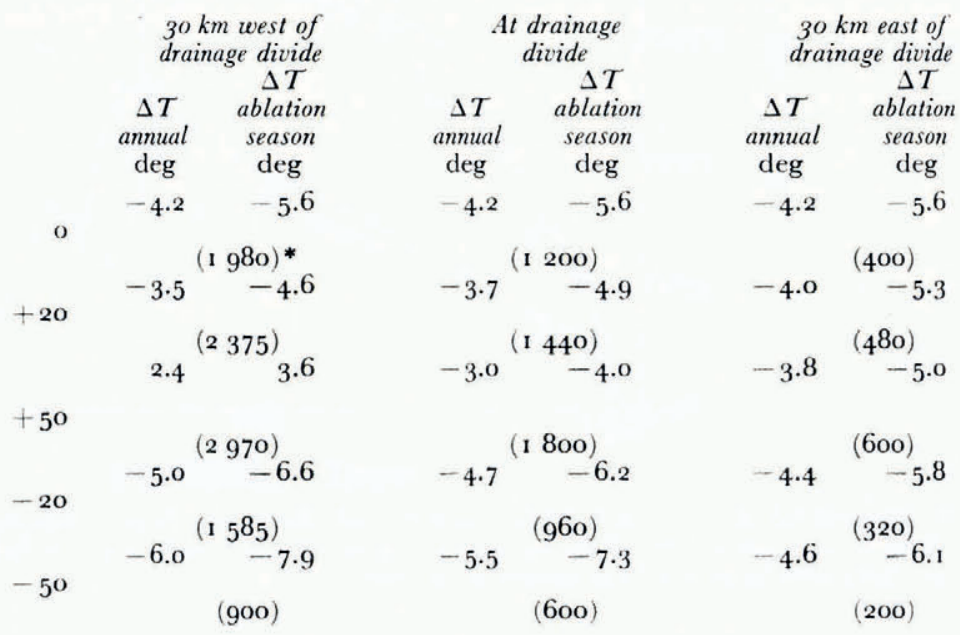

* Precipitation $(\mathrm{mm})$ resulting from percentage change.

If a change of precipitation is assumed, then because of the strong windward-leeward precipitation gradient across the range, a compensating but non-uniform change in temperature at the glaciation threshold would accompany it. The calculation for a given station involves determining the actual precipitation resulting from an assumed percentage change. Then, using the regression equation from Figure 3, the altitude of the glaciation threshold for that precipitation value can be arrived at. The difference between this altitude and that of the present glaciation threshold at the station (Table II) provides a measure of the amount of total depression $(900 \mathrm{~m})$ accounted for by the precipitation change alone. The residual is attributed to temperature change which is calculated using the lapse-rate regression equations of Figure 4 .

Given a $20 \%$ increase in precipitation at each of the three points on the transect, the temperature change required to lower the glaciation threshold by $900 \mathrm{~m}$ is slightly less than if precipitation remained constant (Table III). However, the temperature compensation is greatest at the west end of the transect, where the absolute change of precipitation would be greatest. The effect is even more pronounced if a $50 \%$ increase in precipitation is postulated, for this would require not only a depression of ablation-season temperature by $5 \mathrm{deg}$ at the east end of the transect, but a rise of ablation-season temperature at the west end to $3.6 \mathrm{deg}$ above the present value so as to compensate for an increase in accumulation-season precipitation to nearly $3000 \mathrm{~mm}$.

A decrease in precipitation during the last glaciation would necessitate a lowering of temperature values below those required for no change in precipitation, the effect being greater with decreasing precipitation. For example, a $20 \%$ decrease in accumulationseason precipitation at each of the three points would require a $6.6 \mathrm{deg}$ decrease in ablationseason temperature to lower the glaciation threshold $900 \mathrm{~m}$ at the west end of the transect 
and a temperature depression of $5.8 \mathrm{deg}$ at the east end. An even greater temperature depression would result from a precipitation decrease of $50 \%$, which would bring ablation-season temperatures down by 7.9 and 6.I deg at the two ends of the transect.

Although these postulated cases reflect only an extremely limited number of possible conditions, they probably encompass the actual range of conditions that existed during the last glaciation. A substantial increase in precipitation $(\geqslant 30 \%)$ appears unlikely, for it would require summer temperatures in western Washington to equal or even exceed those of today. Available pollen records indicate quite clearly that temperatures were depressed below those of the present. In fact, such data provide the best means of evaluating possible climatic regimes shown in Table III, for they offer an independent basis for evaluating changes in temperature and precipitation, as read from changing floral conditions in areas adjacent to the Cascade Range.

Late Pleistocene environmental changes along the west coast of the Olympic Peninsula, which probably were broadly similar to those in the Cascades, can be inferred from pollen studies at three sites near sea-level. Heusser (1964, I965) interpreted a detailed pollen record from Humptulips Bog as indicating that the local environment during the maximum ice advance (Evans Creek stade) of the Fraser glaciation was characterized by a mean July temperature 5 deg colder than present and by drier conditions. Allochthonous peats found along the Bogachiel River and deposited during this same interval date to about 18 8oo years B.P. and record a "cold tundra environment" (Heusser, I973). A long pollen record from coastal cliffs at Kalaloch shows two intervals, dated at $c$. I 8 ooo-19 ooo and $c .22$ ooo years ago, when the July temperature was at least $4.5 \mathrm{deg}$ colder than today (Heusser, 1972). These sites occur along a zone where accumulation-season precipitation is currently about $2500 \mathrm{~mm}$. The environmental changes inferred from the pollen data, in conjunction with the derived climatic values of Table III, imply that precipitation at the last glacial maximum was not substantially higher or lower than at present, for an increase of more than $30 \%$ would have led to a negligible temperature change along the western margin of the Cascades and a decrease of more than $30 \%$ would have required a drop in temperature in excess of that indicated. by the pollen data. Accordingly, the climate of the last glacial maximum in the Cascade Range probably was characterized by a change in accumulation-season precipitation of no more than 20 or $30 \%$ from that of today, a drop in ablation-season temperature of about $5.5 \pm 1.5 \mathrm{deg}$, and a decrease in mean annual temperature of about $4.2 \pm \mathrm{r} .0 \mathrm{deg}$.

\section{Acknowledgements}

I am most grateful to John T. Andrews, Richard F. Flint, Gifford H. Miller, Hugh H. Mills and Wendell V. Tangborn for constructive reviews of a preliminary draft of this paper.

MS. received 26 February 1976

\section{REFERENGES}

Ahlmann, H. W. 1948. Glaciological research on the North Atlantic coasts. London, Royal Geographical Society. (R.G.S. Research Series, No. I.)

Andersen, B. G. 1968. Glacial geology of western Troms, north Norway. Norges Geologiske Undersekelse, No. 256.

Andrews, J. T., and Miller, G. H. 1972. Quaternary history of northern Cumberland Peninsula, Baffin Island, N.W.T., Canada. Part IV. Maps of the present glaciation limits and lowest equilibrium line altitude for north and south Baffin Island. Arctic and Alpine Research, Vol. 4, No. I, p. 45-59.

Betteridge, H. T., ed. 1958. The new Cassell's German dictionary. New York, Funk and Wagnalls.

Bradley, R. S. 1975. Equilibrium-line altitudes, mass balance, and July freezing-level heights in the Canadian high Arctic. Journal of Glaciology, Vol. 14, No. 71, p. 267-74.

Charlesworth, J. K. 1957. The Quaternary era, with special reference to its glaciation. London, Edward Arnold. 2 vols. 
Enquist, F. 1916. Der Einfluss des Windes auf der Verteilung der Gletscher. Bulletin of the Geological Institution of the University of Upsala, Vol. 14, p. I-108.

Grosval'd, M. G., and Kotlyakov, V. M. 1969. Present-day glaciers in the U.S.S.R. and some data on their mass balance. Journal of Glaciology, Vol. 8, No. 52, p. 9-22.

Heusser, C. J. 1964. Palynology of four bog sections from the western Olympic Peninsula, Washington. Ecology, Vol. 45, No. 1, p. 23-40.

Heusser, C. J. 1965. A Pleistocene phytogeographical sketch of the Pacific Northwest and Alaska. (In Wright, H. E., jr., and Frey, D. G., ed. The Quaternary of the United States. Princeton, N.J., Princeton University Press, p. $469-83$.)

p. $469-83$.
Heusser, C. J. 1972. Palynology and phytogeographical significance of a late-Pleistocene refugium near Kalaloch, Washington. Quaternary Research, Vol. 2, No. 2, p. I89-201.

Heusser, C. J. 1973. Age and environment of allochthonous peat clasts from the Bogachiel River valley, Washington. Geological Society of America. Bulletin, Vol. 84, No. 3, p. 797-804.

Loewe, F. 1971. Considerations on the origin of the Quaternary ice sheet of North America. Arctic and Alpine Research, Vol. 3, No. 4, p. 331-44.

Meier, M. F. 196r. Distribution and variations of glaciers in the United States exclusive of Alaska. Union Géodésique et Géophysique Internationale. Association Internationale d'Hydrologie Scientifique. Assemblée générale de Helsinki, 25-7-6-8 196o. Commission des Neiges et Glaces, p. 420-29.

Miller, G. H., and others. 1975. The glaciation level and lowest equilibrium line altitude in the high Canadian Arctic; maps and climatic interpretation, by G. H. Miller, R. S. Bradley and J. T. Andrews. Arctic and Alpine Research, Vol. 7, No. 2, p. $155-68$.

Onions, C. T., ed. 1955. The Oxford universal dictionary. Oxford, Clarendon Press.

Østrem, G. 1964. Ice-cored moraines in Scandinavia. Geografiska Annaler, Vol. 46, No. 3, p. 282-337.

Østrem, G. 1964. Ice-cored moraines in Scandinavia. Geografiska Annaler, Vol. 46, No. 3, p. 282-337. Annaler, Vol. $48 \mathrm{~A}$, No. 3 , p. $126-38$.

Østrem, G. 1972. Height of the glaciation level in northern British Columbia and southeastern Alaska. Geografiska Annaler, Vol. 54A, No. 2, p. 76-84.

Østrem, G. [' ${ }^{\mathrm{r}}$ 974.$]$ Present alpine ice cover. (In Ives, J. D., and Barry, R. G., ed. Arctic and alpine environments. London, Methuen, p. 225-5o.)

Partsch, J. 1882. Die Gletscher der Vorzeit in den Karpathen und den Mittelgebirgen Deutschlands. Breslau, Koebner.

Paterson, W. S. B. 1969. The physics of glaciers. Oxford, Pergamon Press. (The Commonwealth and International Library. Geophysics Division.)

Porter, S. C. 1975[a]. Equilibrium-line altitudes of late Quaternary glaciers in the Southern Alps, New Zealand. Quaternary Research, Vol. 5, No. I, p. 27-47.

Porter, S. C. 1975[b]. Glaciation limit in New Zealand's Southern Alps. Arctic and Alpine Research, Vol. 7, No. I,

p. 33-37.
Porter, S. C. 1976. Pleistocene glaciation in the southern part of the North Cascade Range, Washington. Geological Society of America. Bulletin, Vol. 87, No. 1, p. 61-75.

Post, A. S., and others. 197 I. Glaciers in the United States. Inventory of glaciers in the North Cascades, Washington, by A. [S.] Post, D. Richardson, W. V. Tangborn and F. L. Rosselot. U.S. Geological Survey. Professional Paper 705-A.

Weidick, A. 1968. Observations on some Holocene glacier fluctuations in west Greenland. Meddelelser om Gronland, Bd. 165, Nr. 6.

Weidick, A. 1975. Estimates on the mass balance changes of the inland ice since Wisconsin-Weichsel. Gronlands Geologiske Undersogelse. Rapport Nr. 68. 